\title{
The lack of food intake data and the consequences thereof
}

\author{
Van Heerden IV, Nutrition Consultant and Scientific Editor \\ Schönfeldt HC, Professor, Faculty of Natural and Agricultural Sciences, University of Pretoria \\ Correspondence to: Ingrid van Heerden, e-mail: dietdoc@mweb.co.za
} Keywords: food intake data, South Africa

\section{Abstract}

Generally, South African researchers working in the fields of nutrition and dietetics collect food intake data as a first step towards determining the nutritional status of various populations. However, on publication, the majority of the results obtained from these studies are expressed in terms of nutrient intake, whereas food intake data are either not included, or are presented in non-uniform formats. Subsequently, other researchers who wish to determine what foods South Africans are eating are not able to access food intake data from existing studies. For example, if the Food-Based Dietary Guidelines (FBDG), which are expressly based on food, and not nutrient intakes, are to be revised regularly as stipulated by the World Health Organization (WHO), very little additional food intake data from the decade following publication of the first FBDG in 2001 would be available for adult South Africans. It is probable that the consumption of certain foods may have increased because of urbanisation and Westernisation of large sectors of the population. Conversely, economic factors, including the present recession, household food insecurity and poor food choices, may have reduced the intake of nutrient-dense foods in the past decade. The present review describes the disparity in reporting of food intake data, and deficiencies in making data that are available in electronic storage systems accessible to researchers working in the fields of public health nutrition, food production and utilisation, community nutrition and education. The creation of a working committee to make food intake data more accessible is proposed.

(P) Peer reviewed. (Submitted: 2010-11-09, Accepted: 2011-02-04). ๑ SAJCN

S Afr J Clin Nutr 2011;24(1):10-18

\section{Introduction}

Knowledge of food intake is just as important as knowledge of nutrient intake, and collection of the former data generally precedes calculation of the latter findings. Food intake data are required for a variety of applications, over and above estimation of nutrient intake. Most Western countries use powerful food intake studies to determine what their populations eat. Due to economic constraints and lack of personnel, only one national food intake study, the National Food Consumption Survey in Children Aged 1-9 years: South Africa 1999 (NFCS-I-1999), has been completed in South Africa to date. ${ }^{1}$ However, this seminal study did not study the food intake of the entire population, but studied only the food intake of children between the ages of one and nine years. Smaller, less representative, but nevertheless useful studies of the food intake of persons older than nine years have been, and are still, being conducted in South Africa, but over a period of 30 years the number of these studies has decreased dramatically. The purpose of this paper is to highlight the decline in the availability of food intake data in South Africa and to propose solutions to this problem.

\section{Rationale for collecting food intake data}

Knowledge of the food intake data of a population is required to determine which foods a specific population is eating at a given period in time, and to assess in what quantities these foods are being ingested. Once food intake data have been collected, these can be used to calculate the nutrient intake of the given population, a process that is complicated in South Africa by the complex demographics of the population in relation to different ethnic and age groups, highly divergent economic circumstances and different cultural traditions affecting food intake.

In our experience, these divergent population characteristics have presented a challenge to researchers studying food and nutrient intake, and will continue to do so. A clear picture of the food intake of the population is also required to successfully implement national food and nutrition policies, which include the Food Fortification Programme and various school-feeding schemes, and to plan human immunodeficiency virus/acquired immune deficiency syndrome (HIV/ AIDS) nutrition interventions. The regular update of the Food-Based Dietary Guidelines (FBDG) required by the World Health Organization (WHO) must also be based on food intake data. Food intake data also form the basis of nutrient profiling of foods for the purpose of nutrition education, as well as the planning and management of agricultural and health policies. Finally, food intake data are also required to provide feedback to manufacturers and distributors of food products to ensure that the foods produced in this country reach the targeted end consumer. 


\section{A brief overview of national food intake studies in other countries}

The USA has a long history of food intake data collection. The National Health and Nutrition Examination Surveys (NHANES) were initiated as early as 1970, when it became apparent that the study of nutrition and its relationship to health played a pivotal role in determining the well-being of the American population. Since 1999, continuous NHANES surveys have been conducted in the USA to determine what Americans of different ages, ethnic origins and socioeconomic strata eat, and how this impacts on the health of the nation. ${ }^{2}$ Another large, long-term nutrition data collection programme, the Nurses' Health Study (NHS), involving more than 120000 female nurses, has gathered information on food intake in the USA since $1980 .^{3}$

The National Diet and Nutrition Survey (NDNS) programme has also been collecting representative data on the food intake of populations in the UK since 1992. In recent years, the NDNS programme has developed into a series of government-funded surveys of food intake, nutrient intake and nutritional status. ${ }^{4}$

Other countries that have used national food surveys to collect food intake data include the Republic of Ireland (1988-1989) and Northern Ireland (1986-1987), and the two countries together in the North/South Ireland Food Consumption Survey (NSIFCS)(19971999) $)^{5}$; Australia $(1995)^{6}$ and New Zealand $(1997)^{7}$ with the National Nutrition Surveys; and many countries in the European Union with study populations varying in size from 2500 (the Netherlands) to 25000 subjects (Germany). ${ }^{8}$ In addition, studies such as the WHO Multinational MONitoring of Trends and Determinants in CArdiovascular Disease (MONICA) project (17 countries), the EUROpean Community Concerted Action on NUTrition and Health (EURONUT) project (12 countries), the Seven Countries Study (five countries located in Europe) and the International Agency for Research on Cancer (IARC) study on cancer (seven countries in Europe), collect a variety of food intake data from the populations of European countries. ${ }^{8}$

It is evident that many countries throughout the world use national nutrition surveys to obtain information on the food intake of their populations. Most of these surveys use large study populations, and include people from all age groups and from different socioeconomic strata and ethnic origins.

\section{South African national surveys}

In the following section, the limited number of South African national food intake surveys is presented.

\section{Background survey}

In 1994, the SA Vitamin A Consultative Group (SAVACG) undertook a comprehensive national survey on the nutritional status of preschool children in collaboration with the Department of Health, the United Nations Children's Fund and Sight and Life International. ${ }^{9}$

In 1995, in the absence of national food consumption data in any of South Africa's populations, a systematic review of dietary surveys since 1979 was undertaken by the South African National Nutrition Survey Study (SANNSS) group. Despite the small scale and fragmented nature of these studies, nutrient trends were identified that highlighted that dietary deficiencies and wide-spread malnutrition were rife in this country. ${ }^{10}$

The Integrated Nutrition Programme (INP) of the Directorate: Nutrition of the Department of Health included plans for a national micronutrient food fortification programme. At that stage, the following statement already characterised the lack of food intake data availability: "Unfortunately, the available dietary studies on the nutritional status of pre- and primary school children in South Africa are mostly of a small scale and localised. The scientific reports emanating from the latter studies also focus mainly on nutrient intake, rather than on the type and quantities of foods consumed. Therefore, the paucity of such data necessitated the commissioning of a national survey". ${ }^{11}$

\section{National food consumption survey}

The primary objectives of the proposed national survey were to collect baseline information for the formulation of appropriate policy guidelines for food fortification, including the proposal and recommendation of foods that could act as appropriate vehicles for fortification, and for the development of nutrition education material for learners in South Africa. The collection of baseline information included the determination of usual food consumption of children aged one to nine years in South Africa, assessment of the usual nutrient intake of one to nine-year-old children in South Africa, and identification of factors impacting on food consumption and the determination of anthropometric status. ${ }^{11}$

The NFCS-I-1999 was a cross-sectional survey of 2894 children aged one to nine years in South Africa that was conducted from February-July 1999. A nationally representative sample, with provincial representation based on the Census 1996, was used, plus $50 \%$ oversampling to accommodate children who would not be at home (25\%), and allow for over-representation of children living in high-risk areas (25\%) (i.e. areas of low socioeconomic status). ${ }^{11}$

This first South African national food consumption survey was conducted by the nine universities teaching nutrition/dietetics in South Africa and the Medical Research Council (MRC). ${ }^{11}$ The survey found that the five foods most commonly eaten by South African children aged one to nine years were maize meal, sugar, tea, whole milk and brown bread. ${ }^{9}$ Consequently, food fortification of maize meal and wheat flour/bread with eight nutrients was implemented by the Food Fortification Act in April 2003, and became a reality as of October 2003. ${ }^{11}$

\section{Follow-up survey}

A second survey, the National Food Consumption Survey: Fortification Baseline I (NFCS-FB-1), was launched in January 2005, and first reported on in 2007. This second survey was a direct result of the NFCS-I-1999, and was designed to obtain baseline information on the predisposition of people to food fortification, and to establish 
blood micronutrient values in children aged one to nine years and women of childbearing age (16-35 years).

Because this study specifically concentrated on defining attitudes towards the fortification of maize and wheat bread, and the procurement and use of these fortified staples without inclusion of other food intake data, this second-phase study cannot be classified as a food consumption survey per se. ${ }^{12}$

It is evident that only one national food consumption survey has been conducted in South Africa to date, namely the NFCS-I-1999. As yet, no other age groups have been studied on a national level. In 2003, when compiling a secondary data analysis of South African dietary surveys (to provide the Department of Health with a reference table of food items and average amounts consumed by South Africans), Steyn (2003) pointed out that "there has never been a national dietary survey on adults in South Africa", ${ }^{13}$ a situation that has remained unchanged to the present day.

\section{Decreasing availability of food intake data in the period 1979-2010 based on three case studies}

Three literature studies, to determine the intake of specific foods, for the period 1979-2010, were undertaken in 1994, 1999 and 2010. Two of these studies ${ }^{14,15}$ were conducted to determine the sugar intake of the South African population in the periods 19791994 and 1994-1999 for the South African Sugar Association, and one study ${ }^{16}$ was conducted for the South African Milk Producers' Organisation to determine the milk and dairy product intake for the period 2000-2010.

Tables I-III list the number of journal articles, personal communications and university theses relating to studies that investigated food intake in South African populations from 1974-2010. It is evident and disturbing that instead of increasing, as has been the case in other countries such as the USA and UK, studies reporting on the food intake of South African populations are declining steadily (see

Table I: Food intake studies identified during the Sugar Intake Survey for the period 1979-1994

\begin{tabular}{|c|c|c|c|c|}
\hline $\begin{array}{l}\text { Year data } \\
\text { collected }\end{array}$ & $\begin{array}{l}\text { Year data } \\
\text { published }\end{array}$ & Population & References & Organisation \\
\hline \multicolumn{5}{|c|}{ Journal articles and personal communications: adult studies } \\
\hline$N / A^{a}$ & 1987 & $\begin{array}{l}\text { Two groups of } 25 \text { rural, adult black male farm workers, with a high egg } \\
\text { intake, or a normal rural diet, Hekpoort }\end{array}$ & Vorster $\mathrm{HH}$ et $\mathrm{al}^{17}$ & $\begin{array}{l}\text { Potchefstroom University for } \\
\text { Christian Higher Education } \\
\text { (Potch) }\end{array}$ \\
\hline N/A & 1988 & $\begin{array}{l}30 \text { rural coloured adult men and women (average } 39 \text { years) working on } \\
\text { an egg farm in Humansdorp }\end{array}$ & Vorster $\mathrm{HH}$ et al ${ }^{18}$ & Potch \\
\hline $1979 ; 1983$ & $\begin{array}{l}1988 ; \\
1989\end{array}$ & $\begin{array}{l}1113 \text { mainly Afrikaans men and women (15-64 years) in rural Western } \\
\text { Cape, CORIS Study }{ }^{b}\end{array}$ & $\begin{array}{l}\text { Wolmarans } \mathrm{P} \text { et } \mathrm{al}^{19} \\
\text { Wolmarans } \mathrm{P} \text { et } \mathrm{al}^{20}\end{array}$ & Medical Research Council (MRC) \\
\hline 1982 & $\begin{array}{l}1988 ; \\
1994\end{array}$ & $\begin{array}{l}976 \text { adult coloured men and women (15-64 years) in Cape Peninsula } \\
\text { (CRISIC Studyc) }\end{array}$ & 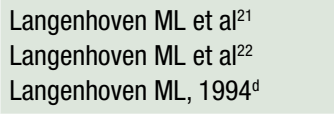 & MRC \\
\hline 1988 & 1990 & $\begin{array}{l}61 \text { adult Venda men (average } 36.6 \text { years) and women (average } \\
33.3 \text { years) in Tshikundamalema, an isolated rural village }\end{array}$ & Vorster $\mathrm{HH}_{\text {et }} \mathrm{al}^{23}$ & Potch \\
\hline N/A & 1992 & $\begin{array}{l}39 \text { elderly white men ( } 51-84 \text { years) with vascular disease in } \\
\text { Stellenbosch, Western Cape }\end{array}$ & Faber $\mathrm{M}$ et $\mathrm{al}^{24}$ & MRC \\
\hline Pre-1991 & $\begin{array}{l}1993 ; \\
1994\end{array}$ & $\begin{array}{l}983 \text { black urban men and women (11-64 years) in the Cape Peninsula } \\
\text { (BRISK Studye) }\end{array}$ & $\begin{array}{l}\text { Bourne LT et a }{ }^{25} \\
\text { Bourne LT et al }{ }^{26}\end{array}$ & MRC \\
\hline N/A & 1994 & 119 Pedi households in Monyamane, Lebowa & Steyn NP, $1994^{b}$ & University of the North (UN) \\
\hline \multicolumn{5}{|c|}{ Journal articles and personal communications: child studies } \\
\hline $1982-1984$ & 1991 & $\begin{array}{l}194 \text { white infants (three to four years), rural Western Cape (CORIS } \\
\text { Study }^{b} \text { ) }\end{array}$ & Langenhoven ML et al, $1991^{27}$ & MRC \\
\hline $1990-1991$ & $1992 ; 1994$ & $\begin{array}{l}118 \text { Pedi preschool children (three to five years), two rural areas of } \\
\text { Lebowa }\end{array}$ & $\begin{array}{l}\text { Steyn NP et al, } 1992^{28} \\
\text { Steyn NP, } 1994^{\text {d }}\end{array}$ & UN \\
\hline $1990-1991$ & $1993 ; 1994$ & $\begin{array}{l}289 \text { Pedi schoolchildren (six to fourteen years), two rural areas of } \\
\text { Lebowa }\end{array}$ & $\begin{array}{l}\text { Steyn NP et al, } 1993^{29} \\
\text { Badenhorst CJ et al, } 1993^{30} \\
\text { Steyn NP, } 1994^{b}\end{array}$ & UN \\
\hline \multicolumn{5}{|c|}{ Theses: adult studies } \\
\hline 1987 & 1988 & $\begin{array}{l}95 \text { adult Zulu women ( } 24-46 \text { years) in remote rural areas of } \\
\text { KwaZulu-Natal }\end{array}$ & De Villiers MA, $\mathrm{MSc}^{32}$ & Stellenbosch University (SU) \\
\hline 1987 & 1988 & $\begin{array}{l}966 \text { first-year female university students aged 18, at Stellenbosch } \\
\text { University }\end{array}$ & Senekal M, MSc ${ }^{33}$ & SU \\
\hline
\end{tabular}




\begin{tabular}{|c|c|c|c|c|}
\hline 1989 & 1990 & $\begin{array}{l}149 \text { female coloured primary school teachers (25-64 years) in Western } \\
\text { Cape }\end{array}$ & Venter I, MSc ${ }^{34}$ & SU \\
\hline N/A & 1990 & $\begin{array}{l}100 \text { "healthy" elderly white men and women (average } 65 \text { years) in } \\
\text { Potchesfroom }\end{array}$ & Kruger A, MSocSc ${ }^{35}$ & $\begin{array}{l}\text { University of the Orange Free } \\
\text { State }\end{array}$ \\
\hline N/A & 1990 & $\begin{array}{l}\text { White and Indian male jockeys (average } 27.8 \text { years) from Johannesburg, } \\
\text { Cape Town, Durban and Port Elizabeth }\end{array}$ & Kotze J, MSc ${ }^{36}$ & SU \\
\hline \multicolumn{5}{|c|}{ Theses: child studies } \\
\hline 1982 & 1983 & $\begin{array}{l}800 \text { children: } 200 \text { white, } 200 \text { coloured, } 200 \text { black and } 200 \text { Indian boys } \\
\text { and girls (all aged 12) in the northern suburbs of Cape Town }\end{array}$ & Steyn NP, MSc ${ }^{37}$ & SU \\
\hline 1985 & 1986 & $\begin{array}{l}872 \text { urban and rural white, black and coloured children (11 years) in the } \\
\text { Cape Province }\end{array}$ & Steyn NP, PhD ${ }^{38}$ & SU \\
\hline 1984 & 1991 & $\begin{array}{l}2800 \text { rural black, white and Indian children (four to five years) in the } \\
\text { Transvaal }\end{array}$ & MacKeown JM, MSc ${ }^{39}$ & University of the Witwatersrand \\
\hline N/A & 1992 & 321 Indian matriculants (average 17 years), Lenasia, Transvaal & Mia FB, MSc ${ }^{40}$ & Potch \\
\hline
\end{tabular}

Table II: Food intake studies identified during the Sugar Intake Survey for the period 1994-1999

\begin{tabular}{|c|c|c|c|c|}
\hline $\begin{array}{l}\text { Year data } \\
\text { collected }\end{array}$ & $\begin{array}{l}\text { Year data } \\
\text { published }\end{array}$ & Population & References & Organisation \\
\hline \multicolumn{5}{|c|}{ Journal articles and personal communications: adult studies } \\
\hline $1988^{\mathrm{a}}$ & $\begin{array}{l}1995 \\
1998\end{array}$ & $\begin{array}{l}312 \text { "healthy" urban white men and women (15-64 years), Witbank and } \\
\text { Vanderbijlpark, Transvaal. (VIGHOR Study) }\end{array}$ & $\begin{array}{l}\text { Vorster HH et al }{ }^{41} \\
\text { Oosthuizen W et al }\end{array}$ & $\begin{array}{l}\text { Potchefstroom University for } \\
\text { Christian Higher Education } \\
\text { (Potch) }\end{array}$ \\
\hline 1986 & 1996 & $\begin{array}{l}97 \text { urban middle-aged white Afrikaans men ( } 35-44 \text { years) in } \\
\text { Bloemfontein }\end{array}$ & Staats A et al ${ }^{43}$ & $\begin{array}{l}\text { University of the Orange Free } \\
\text { State (UFS) }\end{array}$ \\
\hline 1993 & $\begin{array}{l}1997 \\
1998\end{array}$ & 200 elderly coloured men and women (average 73.7 years), Cape Flats & Charlton KE et al ${ }^{44}$ & University of Cape Town (UCT) \\
\hline$N / A^{b}$ & 1998 & 81 HIV-positive patients, Orange Free State & Dannhauser $\mathrm{A}$ et al ${ }^{46}$ & UFS \\
\hline 1997-1998 & 1998 & 210 black rural adults (20-60 years) in Northern Province & Steyn NP et al ${ }^{47}$ & University of the North (UN) \\
\hline N/A & 1999 & $\begin{array}{l}202 \text { pregnant black women, antenatal clinic, Pelonomi Hospital, } \\
\text { Bloemfontein, Orange Free State }\end{array}$ & Dannhauser $\mathrm{A}$ etac & UFS \\
\hline 1996 & 1999 & 82 adult, black male workers (25-64 years), at UFS & Slabber $\mathrm{M}$ et alc & UFS \\
\hline N/A & 2004 & $\begin{array}{l}216 \text { asymptomatic HIV-infected and } 1550 \text { non-HIVc-infected men and } \\
\text { women in North West Province }\end{array}$ & Vorster HH et al ${ }^{48}$ & Potch \\
\hline N/A & 1999 & $\begin{array}{l}776 \text { free-living Indian men and women in the metropolitan area of } \\
\text { Durban }\end{array}$ & Wolmarans $\mathrm{P}$ et al $\mathrm{a}^{49}$ & Medical Research Council (MRC) \\
\hline \multicolumn{5}{|c|}{ Journal articles and personal communications: child studies } \\
\hline 1990 & 1994 & $\begin{array}{l}163 \text { urban black children (three to six years) in the Cape Peninsula } \\
\text { (BRISK Studyc) }\end{array}$ & Bourne LT et al ${ }^{50}$ & MRC \\
\hline N/A & 1994 & 57 white, black, coloured, Indian boys, (eight to ten years), Doorfontein & Vorster $\mathrm{HH}$ et al ${ }^{51}$ & Potch \\
\hline 1991 & 1994 & 96 black primary school children (six to fourteen years) in rural Lebowa & Tichelaar HY et al52 & MRC \\
\hline N/A & 1994 & $\begin{array}{l}31 \text { children (average two to three years) with failure to thrive in Bishop } \\
\text { Lavis, Cape Town, and matched controls }\end{array}$ & Van Staden E et al ${ }^{53}$ & MRC \\
\hline 1988 & 1994 & $\begin{array}{l}389 \text { black rural and urban children (11 years) in KwaZulu-Natal and } \\
\text { Namibia }\end{array}$ & MacKeown JM et al ${ }^{54}$ & $\begin{array}{l}\text { MRC/University of the } \\
\text { Witwatersrand (WITS) }\end{array}$ \\
\hline 1991 & 1996 & $\begin{array}{l}2059 \text { black, coloured, Indian and white urban one-year-old children in } \\
\text { Soweto, Johannesburg [Birth-to-Ten (Bt10) Study] }\end{array}$ & MacKeown JM et al55 & WITS \\
\hline 1994 & 1996 & $\begin{array}{l}323 \text { black preschool children (six months to six years) on farms where } \\
\text { the Rural Foundation was present or absent in Bloemfontein District, UFS }\end{array}$ & Dannhauser A et a ${ }^{56}$ & UFS \\
\hline $\mathrm{N} / \mathrm{A}$ & 1997 & $\begin{array}{l}\text { Black urban and rural disadvantaged infants (average } 4.5 \text { years) and } \\
\text { children (up to two years) in Kayamandi, Western Cape; and Ndunakazi, } \\
\text { KwaZulu-Natal }\end{array}$ & Faber $\mathrm{M}$ et al ${ }^{57}$ & MRC \\
\hline
\end{tabular}




\begin{tabular}{|c|c|c|c|c|}
\hline $1984-1985$ & 1998 & Five-year-olds in Bt10 Study & Mackeown JM et al ${ }^{58}$ & WITS \\
\hline N/A & 1999 & $\begin{array}{l}231 \text { black preschool children (two to } 5.9 \text { years) in informal settlements } \\
\text { (Joe Slovo and Mafora), near Bloemfontein, Orange Free State }\end{array}$ & Dannhauser $A$ et alc ${ }^{c}$ & UFS \\
\hline \multicolumn{5}{|c|}{ Theses: adult studies } \\
\hline N/A & 1998 & $\begin{array}{l}890 \text { adult black men and women divided into rural, farm workers, } \\
\text { informal settlement, middle-class urban and upper-class urban subjects } \\
\text { in North West Province, (THUSA Study) }\end{array}$ & Maclntyre UE, PhD ${ }^{59}$ & Potch \\
\hline 1998 & 1999 & $\begin{array}{l}58 \text { black mothers and caregivers (average } 36 \text { years) with stunted or } \\
\text { non-stunted children in rural areas of Northern Province (NutriGro Study') }\end{array}$ & Amissah A, MSc ${ }^{60}$ & Pretoria Technikon \\
\hline \multicolumn{5}{|c|}{ Theses: child studies } \\
\hline 1998 & 1999 & $\begin{array}{l}58 \text { black stunted or non-stunted children (12-24 months) in rural areas } \\
\text { of Northern Province (NutriGro Study) }\end{array}$ & Amissah A, MSc ${ }^{60}$ & Pretoria Technikon \\
\hline
\end{tabular}

$\mathrm{a}=$ VIGHOR Study

${ }^{b}=$ Not available

${ }^{c}=$ Personal communication

${ }^{d}=$ THUSA Study

Table III: Food intake studies identified during the Milk and Dairy Product Intake Survey for the period 2000-2010

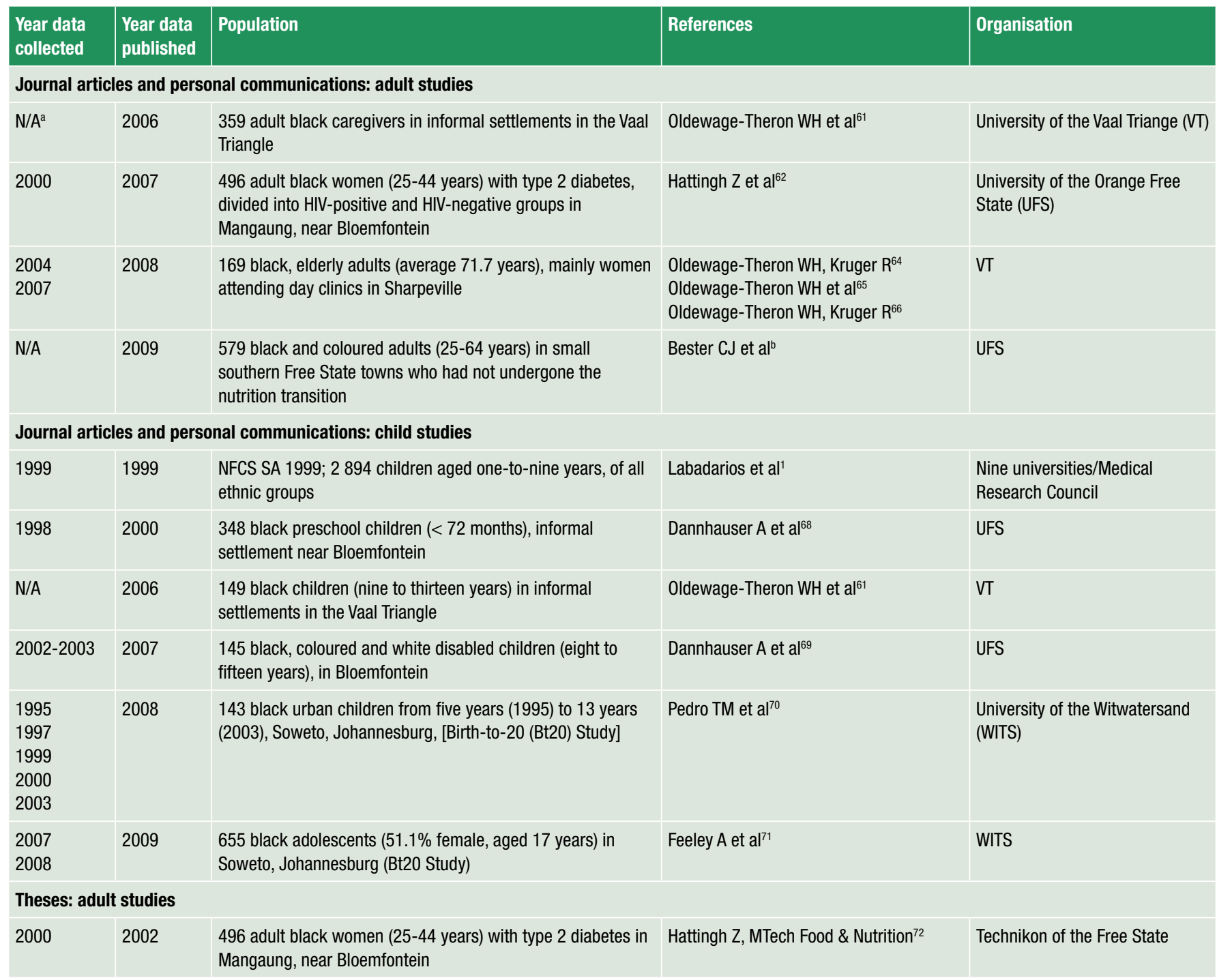

${ }^{\mathrm{a}}=$ Not available

$\mathrm{b}=$ Personal communication 
Table IV). The results of the two literature surveys conducted in 1994 and 1999 to determine the sugar intake of South African populations groups are shown in Tables I and II. The results obtained with a literature survey conducted in 2010 to determine the milk/dairy intakes of South African populations groups are shown in Table III.

\section{Decreasing number of food intake studies and theses 1979-2010}

Tables I-III show that the number of food intake studies reported has declined exponentially over time (see Table IV). There has also been a marked change in the populations groups selected for study (see Table V).

Table IV: Decreasing number of food intake studies and theses in the period 1979-2010

\begin{tabular}{|l|c|c|c|}
\hline & $\begin{array}{c}\text { Sugar Intake } \\
\text { Survey } \\
1979-1994\end{array}$ & $\begin{array}{c}\text { Sugar Intake } \\
\text { Survey } \\
1994-1999\end{array}$ & $\begin{array}{c}\text { Milk and Dairy } \\
\text { Intake Survey } \\
2000-2010\end{array}$ \\
\hline Adults & \multicolumn{2}{|c|}{} \\
\hline Number of journal articles & 9 & 9 & 6 \\
\hline Number of studies & 13 & 11 & 5 \\
\hline Personal communications & 2 & 3 & 1 \\
\hline Theses & 5 & 2 & 1 \\
\hline Total & $\mathbf{2 9}$ & $\mathbf{2 5}$ & $\mathbf{1 3}$ \\
\hline Children & & 10 & 7 \\
\hline Number of journal articles & 5 & 11 & $6^{\mathrm{a}}$ \\
\hline Number of studies & 8 & 1 & 0 \\
\hline Personal communications & 2 & 1 & 0 \\
\hline Theses & 4 & $\mathbf{2 3}$ & 13 \\
\hline Total & $\mathbf{1 9}$ & $\mathbf{4 8}$ & $\mathbf{2 6}$ \\
\hline Total adults and children & $\mathbf{4 8}$ & & \\
\hline a = Includes NFcs-1999 and Bt20 & & & \\
\hline
\end{tabular}

Table IV shows that in the period 1979-2010, the number of studies to determine the food intake of adults in South Africa decreased from 13 to five, while the number of studies on children decreased from a peak of 11 to six. The more recent studies of children include the extensive NFCS-I-19991 and the ongoing Birth-to-20 (Bt20) Study. ${ }^{70,71}$ In addition, the number of Master's and Doctoral theses published at universities featuring food intake data decreased in the last 30 years from nine to only one thesis, while the number of personal communications, which are indicative of intake data accessibility, decreased from four to one from the first to the third period. Therefore, there has been a pronounced decrease in the number of investigations collecting food intake data in South African populations in the past 30 years.

It is evident from Table V that for the period 1979-2010, studies of adult black urban subjects, usually living in poor socioeconomic conditions such as informal settlements and squatter camps, increased from one ${ }^{25}$ to four studies, ${ }^{61,62,64,72}$ while studies of adult black rural subjects showed a simultaneous decrease from four studies $^{17,23,32}$ (Steyn 1994, personal communication) to only one
Table V: Decrease in the number of population groups studied in the period 1979-2010

\begin{tabular}{|c|c|c|c|c|}
\hline \multicolumn{2}{|c|}{ Population groups } & \multirow[t]{2}{*}{$\begin{array}{c}\text { Sugar Survey } \\
1979-1994\end{array}$} & \multirow[t]{2}{*}{$\begin{array}{c}\text { Sugar Survey } \\
1994-1999\end{array}$} & \multirow[t]{2}{*}{$\begin{array}{l}\text { Milk and Dairy } \\
\text { Survey 2000-2010 }\end{array}$} \\
\hline Adults & & & & \\
\hline Black & $\begin{array}{l}\text { Urban } \\
\text { Rural }\end{array}$ & $\begin{array}{l}1 \\
4\end{array}$ & $\begin{array}{l}4 \\
4\end{array}$ & $\begin{array}{l}4 \\
1\end{array}$ \\
\hline Coloured & $\begin{array}{l}\text { Urban } \\
\text { Rural }\end{array}$ & $\begin{array}{l}2 \\
1\end{array}$ & $\begin{array}{l}1 \\
0\end{array}$ & $\begin{array}{l}0 \\
1\end{array}$ \\
\hline White & $\begin{array}{l}\text { Urban } \\
\text { Rural }\end{array}$ & $\begin{array}{l}4 \\
1\end{array}$ & $\begin{array}{l}2 \\
0\end{array}$ & $\begin{array}{l}0 \\
0\end{array}$ \\
\hline Indian & $\begin{array}{l}\text { Urban } \\
\text { Rural }\end{array}$ & $\begin{array}{l}1 \\
0\end{array}$ & $\begin{array}{l}1 \\
0\end{array}$ & $\begin{array}{l}0 \\
0\end{array}$ \\
\hline \multicolumn{5}{|l|}{ Children } \\
\hline Black & $\begin{array}{l}\text { Urban } \\
\text { Rural }\end{array}$ & $\begin{array}{l}3 \\
5\end{array}$ & $\begin{array}{l}7 \\
5\end{array}$ & $\begin{array}{l}6^{a} \\
1^{b}\end{array}$ \\
\hline Coloured & $\begin{array}{l}\text { Urban } \\
\text { Rural }\end{array}$ & $\begin{array}{l}2 \\
1\end{array}$ & $\begin{array}{l}3 \\
0\end{array}$ & $\begin{array}{l}2^{\mathrm{b}} \\
1^{\mathrm{b}}\end{array}$ \\
\hline White & $\begin{array}{l}\text { Urban } \\
\text { Rural }\end{array}$ & $\begin{array}{l}4 \\
1\end{array}$ & $\begin{array}{l}2 \\
0\end{array}$ & $\begin{array}{l}2^{b} \\
1^{b}\end{array}$ \\
\hline Indian & $\begin{array}{l}\text { Urban } \\
\text { Rural }\end{array}$ & $\begin{array}{l}3 \\
0\end{array}$ & $\begin{array}{l}2 \\
0\end{array}$ & $\begin{array}{l}1^{\mathrm{b}} \\
0\end{array}$ \\
\hline
\end{tabular}

study (Bester et al, 2009, personal communication) in the last decade. Studies of black urban children increased from three ${ }^{37,38 \text {, }}$ ${ }^{39}$ to six studies $1,61,68,69,70,71$ (including the NFCS-I-1999 and Bt20), while studies of black rural children decreased from five $28,30,31,38,39$ to a single study ${ }^{1}$ in the last 10 years.

Research studies to determine the food intake of black subjects seem to increasingly concentrate on studying urban adults and children living in poor socioeconomic conditions. Less attention is being given to rural black populations, probably in keeping with rapid urbanisation trends. No national studies have reported on the food intake of middle-class black urban populations. It would be worthwhile to monitor the changes that have taken place with regard to food intake in this group, as it has become more affluent and increasingly adopts Western eating patterns.

After 1999, no studies researching the food intake of coloured urban adults have been found. Studies of coloured rural adults remain scarce, as only one study ${ }^{16}$ (Bester et al, 2009, personal communication) was reported in both the first and third periods. Studies of coloured urban children remain constant as two studies in the first ${ }^{37,38}$ and second ${ }^{1,69}$ periods, while studies of coloured rural children are rare. Only one study was published in both the first ${ }^{38}$ and third ${ }^{1}$ periods. No studies have recently been conducted on urban, middle-class coloured populations.

In the period 1979-2010, four studies of the food intake of white urban adults were identified in the first period $24,33,35,36$, two in the second period, ${ }^{41,43}$ and none in the decade from 2000-2010. Studies of the food intake of white rural adults have always been limited, and only one study ${ }^{19}$ was reported for the entire period from 1979. 
Food intake studies on white urban children have halved from four studies in the first period ${ }^{27,37,38,39}$ to two studies ${ }^{1,69}$ in the third period, while only one study was reported for both the first ${ }^{38}$ and third ${ }^{1}$ periods for white rural children.

Research studies on white rural and urban populations have decreased in the past 30 years, and no studies have recently been carried out on adult white urban and rural populations. There are no available data from which to draw conclusions regarding any changes in eating habits that may have occurred in the white population of South Africa in the last decade.

Studies of the food intake of the South African Indian population have always been limited. In urban Indian adults, only one study was reported in the first ${ }^{36}$ and second ${ }^{49}$ periods, and the number of studies to determine the food intake of urban Indian children and adolescents decreased from three in the first period ${ }^{37,39,40}$ to only one study ${ }^{1}$ in the last decade.

There has been a marked reduction in the number of food intake studies reported for all South African population groups over the last 30 years. The decade from 2000-2010 has seen the most pronounced decline in food intake data gathering, a situation that may be due to a decrease in the number of active researchers and a lack of funds at previously productive organisations.

\section{Discrepancies in food intake data reporting}

Another factor that complicates any attempts to understand what South African populations eat, is the discrepancy in food intake data reporting. Table VI lists the type of descriptors that researchers used to express food intake data in their publications, and illustrates the inconsistencies that characterise food intake data reporting, a tendency that is not unique to South Africa. Probably the most useful way to report food intake data is in grams (g) for solid, or millilitres (ml) for liquids per day. Preferably, food intake data should not only be reported as the percentage energy derived from a given food (e.g. sugar), as this complicates the calculation of the actual quantity ingested. Where possible, food intake should also not only be reported in terms of frequency or ranking, as this too gives no indication of quantity ingested. Complicated presentations of data should be avoided, or accompanied by intake expressed in $\mathrm{g}$ or $\mathrm{ml}$ per day.

In addition, publications which only report nutrient intake should be able to provide food intake data on request in a user-friendly and accessible format (e.g. electronic storage). It is also recommended that this be preceded or accompanied by a separate publication, in the same or another journal, devoted to the actual food intake of the population that was studied.

\section{Lack of differentiation when reporting food intake data}

Other deficiencies in the presentation of food intake data occur when authors do not define foods accurately. In the case of sugar, a great deal of confusion exists. Data have been reported in terms of sugar, sugars, table sugar, added sugar and intrinsic and extrinsic sugar, with differentiations between sugar occurring naturally in foods such as fruit and fruit juices; and milk and sugar that is added to certain foods, such as porridges, tea and coffee.

With regard to the intake of foods derived from animal origin, there is an even greater lack of descriptive consistency, especially for meat consumption. The overall descriptor "meat" can include red meat, white meat, mutton/lamb, beef, pork, offal, organ meats, venison, poultry (including ostrich and game birds), sausages made exclusively from meat and fat derived from animals, sausages made mainly from meat off-cuts, fat, textured vegetable protein and starches, processed meats made exclusively from meat, such as ham, or products made with added soy protein, and ready-toeat meals that contain a meat component (lasagne made with beef mince, take-away hamburgers and pies). Studies to determine which foods that are derived from animals are being consumed by the different population groups in South Africa are generally not well defined or differentiated.

Table VI: The number of publications showing a lack of reporting consistency for food intake data

\begin{tabular}{|c|c|c|c|}
\hline \multirow[b]{2}{*}{ Descriptor reported } & \multicolumn{3}{|c|}{ Number of publications } \\
\hline & $\begin{array}{c}\text { Sugar Intake Survey } \\
1979-1994\end{array}$ & $\begin{array}{l}\text { Sugar Intake Survey } \\
\text { 1994-1999 }\end{array}$ & $\begin{array}{l}\text { Milk and Dairy Intake } \\
\text { Survey 2000-2010 }\end{array}$ \\
\hline Grams (g) sugar per day or week; $\mathrm{g} / \mathrm{ml}$ dairy per day or week & 17 & 15 & 3 \\
\hline Percentage of energy derived from sugar & 5 & 10 & - \\
\hline Frequency of consumption, food item ranking, or consumption pattern & 10 & 3 & 4 \\
\hline Money spent on sweetened foods or drinks & 1 & 0 & - \\
\hline Total sugar or cold drink purchased per household & 1 & 0 & - \\
\hline Percentage contribution of basic food group to sugar intake & 1 & 1 & - \\
\hline Percentage of infants consuming sugar-containing foods and drinks & 0 & 1 & - \\
\hline $\begin{array}{l}\text { Ratio of number of food items recorded in each of the six food groups at each } \\
\text { inception (X/total number of food items for all six food groups for each inception) }\end{array}$ & 0 & 0 & 1 \\
\hline No food intake data published, only nutrient intakes & 0 & 0 & 2 \\
\hline
\end{tabular}




\section{Conclusion}

In 1999, it was already evident that the majority of studies investigating food and dietary intake in South Africa concentrated on black populations, with particular emphasis on black subjects of all ages living in urban disadvantaged areas, such as informal settlements and squatter camps. This emphasis is perfectly justified in terms of the demographics of this country, but it has led to a lack of information regarding the food intake of other smaller population groups and rural populations (white, coloured and Indian), coupled with a lack of information on the emerging black middle class. It would be relevant to know whether the more affluent black population has adopted the negative aspects of the Western diet only (high fat, sugar and salt, highly refined foods and large intakes of sweetened cold drinks and alcohol), or whether they are starting to apply some of the more positive features of Western diets (higher intakes of fruit, vegetables, high-fibre grains and milk and dairy products).

There is a paucity of studies conducted and published on nutrient and food intake in South Africa in the period 2000-2010. This appears to be primarily due to budget contraints and a lack of researchers at a number of previously active organisations (e.g. certain universities and research institutes).

The skewed age emphasis of large studies is also of concern. The most representative study of food intake is the NFCS-I-1999, which studied children one-to-nine years of age $(n=2894) .{ }^{1}$ The followup study, the NFCS-FB-II of $2005,{ }^{12}$ concentrated on the nutritional status of children of one to nine years of age and included women of childbearing age, but did not produce actual food intake data. Consequently, general post-2000 knowledge of the food intake of adults in South Africa remains limited.

The problem of emphasis in the published papers also contributes to the lack of knowledge on food intake data. With few exceptions, the majority of papers published in the past decade only report nutrient intake (e.g. macronutrients, vitamins and minerals) and omit the actual food intake from which these data were obtained. Most of the authors who were contacted in retrospect to try and obtain food intake data, were either unable or unwilling to provide this information. So although each one of the studies published on nutrient intake in South African populations in the past decade is based on food intake data, these data are usually not published, or are not available. Finally, the heterogeneity of the South African population has always posed a problem with regard to food intake and nutrient surveys.

The lack of food intake data continues to be an obstacle in terms of long-term planning for the production of crops and other agricultural commodities, and the nutrient profiling of foods for the purpose of nutrition education. As a foundation, accurate and representative food intake data are therefore essential to plan and manage agricultural and health policies aimed at improving the nutritional status of the population. ${ }^{73}$

\section{Recommendations}

The authors would like to suggest that researchers who plan food and/or nutrient intake studies make provision for storing food intake data in such a format that the data are more readily available on request to interested parties. Researchers should also consider publishing additional papers describing the food intake of their study population.

Food intake data should be expressed in a more user-friendly format, for example in $\mathrm{g}$ or $\mathrm{ml}$ per day instead of frequency rankings or number of intakes, or in terms of highly complicated constructs. An attempt should be made to reach agreement on how to express the intakes of foods such as sugar in a uniform way (for example in $\mathrm{g}$ of added sugar per day instead of the percentage energy derived from sugar). A clear differentiation of complex food groups, such as meat products, would help to clarify available data for the purpose of drawing more meaningful conclusions.

In the absence of ongoing national food intake studies, consideration should be given to also conducting future studies on population groups that have been neglected in the past decade. These include rural populations; black and coloured adults, children and adolescents from higher economic strata; white and Indian adults, children and adolescents; as well as the elderly in all population groups from varying economic strata; and impoverished populations.

Greater cooperation and coordination between research institutes should be encouraged so that more comprehensive information on the food intake of South African populations can be obtained to facilitate the implementation of national food and nutrition policies. Coordinated research on South African food intake could also facilitate planning and management of agricultural policies, and provide feedback to food manufacturers and distributors.

The feasibility of creating a working committee to make South African food intake data more accessible and useable should be investigated and encouraged. It should be kept in mind that the FBDG are tailored to food intake, but our knowledge of what South Africans eat is fragmented, partially outdated and incomplete.

\section{References}

1. Labadarios D, Steyn NP, Maunder E, et al. The National Food Consumption Survey (NFCS). Children aged one-to-nine years, South Africa, 1999. Pretoria: Department of Health.

2. Cox CS, Rothwell ST, Madans JH, et al. Plan and operation of the National Health and Nutrition Examination Surveys (NHANES) I epidemiological follow-up study, 1987. Vital Health Stat.1992;1(27):1-190.

3. Nurses' Health Study. 2008 [homepage on the Internet]. c2010. Available from: http:www.channing. harvard.edu/nhs/index.php/history

4. Ashwell M, Barlow S, Gibson S, Harris C. National diet and nutrition surveys: the British experience. Pub Health Nutr. 2006;9(4):523-530

5. Strain JJ. The North/South Ireland Food Consumption Survey. Pub Health Nutr. 2001;4(5A):1027-1028.

6. Australian Bureau of Statistics. 1995 National Nutrition Survey. National survey nutrient intakes and physical measurements, Australia 1995. Canberra [homepage on the Internet]. c2010. Available from:http://www.abs.gov.au

7. New Zealand Ministry of Health. NZ food: NZ people. Key results of the 1997 National Nutrition Survey. 1999 [homepage on the Internet]. c2010. Available from: http://www.moh.govt.nz

8. Bloemberg BPM, Kromhout D. Nutritional surveys: ongoing activities in Europe. Proc Nutr Soc. 1991;50:681-685.

9. South African Vitamin A Consultative Group (SAVACG). Anthropometric, vitamin A, iron and immunisation coverage status in children aged six-71 months in South Africa. S Afr Med J. 1996:86(4):354-357.

10. Vorster HH, Jerling JC, Oosthuizen W, et al. Nutrient intakes of South Africans. An analysis of the literature (SANNSS Group Report). Isando: Roche; 1995. 
11. National Food Consumption survey in children aged one-to-nine years: South Africa 1999. Part l methodology, sociodemographic and anthropometric data. 2000. Directorate Nutrition, Department of Health. Distributed by the Vitamin Information Centre

12. Labadarios D, Swart R, Maunder E, et al. The National Food Consumption Survey: Fortification Baseline (NFCS-FB-II): South Africa, 2005. Directorate Nutrition, Department of Health: Pretoria; 2007.

13. Steyn NP. Secondary data analyses of dietary surveys undertaken in South Africa to determine usual food consumption of the population. 2003 [homepage on the Internet]. c2010. Available from:http:// journals.cambridge.org/

14. Van Heerden IV. Sugar consumption in South Africa. A survey of the literature published in the period 1979-1994. March 1994. Prepared for the South African Sugar Association.

15. Van Heerden IV. Sugar consumption in South Africa. A survey of the literature published in the period 1994-1999. October 1999. Prepared for the South African Sugar Association.

16. Van Heerden IV. Literature survey on dairy intake in South Africa, 2000-2010. January 2010. Prepared for MilkSA/SAMPRO

17. Vorster $\mathrm{HH}$, Silvis N, Venter CS, et al. Serum cholesterol, lipoproteins, and plasma coagulation factors in South African blacks on a high-egg, but low-fat intake. Am J Clin Nutr. 1987;46(1):52-57.

18. Vorster HH, Venter CS, Silvis $\mathrm{N}$, et al. Influence of a habitual high egg intake on serum lipid levels in a rural coloured population. S Afr Med J. 1988;74:554-559.

19. Wolmarans P, Langenhoven ML, Benade AJS, et al. Intake of macronutrients and their relationship with total cholesterol and high-density lipoprotein cholesterol. The Coronary Risk Factor Study, 1979. S Afr Med J. 1988;73:12-15.

20. Wolmarans P, Langenhoven ML, Van Eck M, Swanepoel ASP. The contribution of different food groups to the energy, fat and fibre intake of the Coronary Risk Factor Study (CORIS) population. S Afr Med J. 1989;75:167-171.

21. Langenhoven ML, Steyn K, Van Eck M, Gouws E. Nutrient intake in the coloured population of the Cape Peninsula. Ecol Food Nutr .1988;22:97-106

22. Langenhoven ML, Steyn K, Van Eck M. The food and meal patterns in the Cape Peninsula coloured population. Ecol Food Nutr. 1988;22:107-116.

23. Vorster HH, Venter CS, Silvis N, et al. Nutrient intakes and vitamin status of adult volunteers in Tshikundamalema, an isolated rural village in Venda. S Afr J Food Sci Nutr. 1990; Abstracts of Biennia Congress held in Cape Town in March 1990:12.

24. Faber $\mathrm{M}$, Kriek JA, Wolmarans $\mathrm{P}$, et al. Dietary patterns and nutritional status in free-living older white men with established vascular disease. S Afr Med J. 1992;82:232-236.

25. Bourne $L T$, Langenhoven ML, Steyn $\mathrm{K}$, et al. Nutrient intake in the urban African population of the Cape Peninsula, South Africa. The Brisk Study. Cent Afr J Med. 1993;39(12):238-247.

26. Bourne LT, Langenhoven ML, Steyn K, et al. The food and meal patterns in the urban African population of the Cape Peninsula, South Africa. The Brisk Study. Cent Afr J Med. 1994;40(6):140-148

27. Langenhoven ML, Swanepoel ASP, Steyn K, et al. Macronutrient intake of preschool children and the contribution of specific food groups. S Afr J Food Sci Nutr. 1991;3(1):6-9.

28. Steyn NP, Badenhorst CJ, Nel JH, Jooste PL. The nutritional status of Pedi preschool children in two rura areas of Lebowa. S Afr J Food Sci Nutr. 1992;4(2):24-28.

29. Steyn NP, Badenhorst CJ, Nel JH. The meal patterns and snacking habits of schoolchildren in two rura areas of Lebowa. S Afr J Food Sci Nutr. 1993;5(1):5-9

30. Badenhorst CJ, Steyn NP, Jooste PL, et al. Nutritional status of Pedi schoolchildren aged six-14 years in two rural areas of Lebowa: a comprehensive nutritional survey of dietary intake, anthropometric, biochemical, haematological and clinical measurements. S Afr J Food Sci Nutr. 1993;5(4):112-119.

31. Reitsma GM, Vorster HH, Venter CS, et al. A school feeding scheme did not improve nutritional status of a group of black children. S Afr J Clin Nutr. 1994;7(1):10-18

32. De Villiers MA. Diet, life-styles and the prevalence of obesity and hypertension among Zulu women in a remote rural area. MSc thesis, University of Stellenbosch; 1988

33. Senekal M. Factors related to weight gain experienced by first-year female students in residences at the University of Stellenbosch. MSc thesis, University of Stellenbosch; 1988.

34. Venter I. Oorgewig en vetsug: ' $n$ empiriese ondersoek na oorsaaklike faktore by laerskool onderwyseresse in diens van die Raad van Verteenwoordigers in die Kaapse Skiereiland. MSc thesis, University of Stellenbosch; 1990.

35. Kruger A. 'n Verpleegkundige beraming van die voedingstatus van "gesonde", vrylewende bejaardes. MSocSc thesis, University of the Orange Free State; 1990.

36. Kotze J. Assessment of the dietary intake of jockeys in South Africa. MSc thesis, University of Stellenbosch; 1990

37. Steyn NP. Sucrose consumption and dental health of 12-year-old white, coloured, black and Indian children residing in the northern suburbs of Cape Town. MSc thesis, University of Stellenbosch; 1983.

38. Steyn NP. Nutritional status of 11-year-old children in the Western Cape Province of South Africa. PhD thesis, University of Stellenbosch; 1986

39. Mackeown JM. Comparison of total individual foodstuff intakes among four- and five-year-old children in three South African ethnic populations. MSc thesis, University of the Witwatersrand; 1991.

40. Mia FB. Habitual dietary intakes and levels of risk factors associated with coronary heart disease among Indian matriculants in Lenasia. MSc thesis, Potchefstroom University for Higher Christian Education; 1992.

41. Vorster HH, Oosthuizen W, Steyn HS, et al. Nutrient intakes of white South Africans: a cause for concern: the VIGHOR Study. S Afr J Food Sci Nutr. 1995;7(3):119-126.

42. Oosthuizen W, Van der Merwe AM, Kotze JP, et al. Dietary composition and body mass index at different levels of added sugar consumption: the VIGHOR Study. S Afr Med J. 1998;88(9):1212-1217.

43. Staats A, Dannhauser A, Vermaak WJH. The relationship between socioeconomic status and risk factors for ischaemic heart disease in middle-aged Afrikaans-speaking men in Bloemfontein. S Afr J Food Sci Nutr. 1996;8(1):26-32
44. Charlton KE, Wolmarans P, Marais AD, Lombard GJ. Macronutrient intake and cardiovascular risk factors in older coloured South Africans. East Afr Med J. 1997;74(8):478-486.

45. Charlton KE, Wolmarans P, Lombard CJ. Evidence of nutrient dilution with high sugar intake in older South Africans. J Hum Nutr Diet. 1998;11:331-343.

46. Dannhauser A, Van Staden M, Van der Ryst E, et al. Nutritional status of HIV-1 seropositive patients in the Free State Province of South Africa: anthropometric and dietary profile. Eur J Clin Nutr. 1998:52:1-9.

47. Steyn N, Burger S, Monyeki K, et al. Dietary intake of the adult population of Dikgale. University of the North, Sovenga; 1998.

48. Vorster $\mathrm{HH}$, Kruger A, Margetts BM, et al. The nutritional status of asymptomatic HIV-infected Africans: directions for dietary intervention? Pub Health Nutr. 2004:7(8):1055-1064.

49. Wolmarans P, Seedat YK, Mayet FGH, et al. Dietary intake of Indians living in the metropolitan area of Durban. Pub Health Nutr. 1999;2(1):55-60

50. Bourne LT, Langenhoven ML, Steyn K, et al. Nutritional status of three- to-six-year-old African children in the Cape Peninsula. East Afr J Med. 1994;71:695-702.

51. Vorster HH, Barnard HC, Reitsma GM, et al. Nutritional status of eight- to ten-year-old white, black, coloured and Indian boys in a multicultural school. S Afr J Food Sci Nutr. 1994;6(1):18-23.

52. Tichelaar HY, Steyn NP, Badenhorst CJ, et al. Epidemiological evidence of impaired fatty acid status of undernourished rural primary schoolchildren in Lebowa. S Afr J Food Sci Nutr. 1994;6(2):60-65.

53. Van Staden E, Langenhoven ML, Donald PR, Laubscher JA. Dietary intake of children with failure to thrive. S Afr J Food Sci Nutr. 1994:6(3):90-93

54. Mackeown JM, Cleaton-Jones PE, Hargreaves, JA. Variety of individual food items consumed by 11-year-old children in KwaZulu and Namibia. Ecol Food Nutr. 1994;33:27-36.

55. MacKeown JM, Cleaton-Jones PE, Perdrau GG. Energy and macronutrient intake of one-year-old South African urban children: the Birth-to-Ten (Bt10) Study. Paediatr Perinat Epidemiol. 1996;10:150-160.

56. Dannhauser A, Joubert G, Nel M. Nutritional status of preschool children in the Bloemfontein district. S Afr J Food Sci Nutr. 1996;8(1):14-22.

57. Faber M, Oelofse A, Kriek JA, Benadé AJS. Breastfeeding and complementary feeding practices in a low socioeconomic urban and a low socioeconomic rural area. S Afr J Food Sci Nutr. 1997;9(2):43-51.

58. MacKeown JM, Cleaton-Jones PE, Edwards AW, Turgeon-0'Brien H. Energy, macro- and micronutrient intake of five-year-old urban black South African children in 1984 and 1995. Paediatr Perinat Epidemiol. 1998;12:297-312.

59. Maclntyre UE. Dietary intakes of Africans in transition in the North West Province. PhD thesis, Potchefstroom University for Christian Higher Education, Potchefstroom; 1998.

60. Amissah A. Inadequate dietary intakes as a cause of stunting among young children in rural South Africa. MSc Thesis, Technikon Pretoria; 1999

61. Oldewage-Theron WH, Dicks EG, Napier CE. Poverty, household food insecurity and nutrition: coping strategies in an informal settlement in the Vaal Triangle, South Africa. Pub Health Nutr. 2006:120:795-804.

62. Hattingh Z, Walsh C, Veldman FJ, Bester CJ. Micronutrient intake of HIV-infected women in Mangaung Free State. S Afr J Clin Nutr. 2007:20(1):28-36.

63. Hattingh Z, Walsh CM, Bester CJ, Oguntibeju 00. An analysis of dietary micronutrient intakes in two age groups of black South African women. West Indian Med J. 2008;57(5):431-437.

64. Oldewage-Theron WH, Kruger R. Food variety and dietary diversity as indicators of the dietary adequacy and health status of an elderly population in Sharpeville, South Africa. J Nutr Elder. 2008;27(1/2):101-135

65. Oldewage-Theron WH, Samuel OF, Venter CS. Zinc deficiency among the elderly attending a care centre in Sharpeville, South Africa. J Hum Nutr Diet. 2008;21:566-574.

66. Oldewage-Theron WH, Kruger R. Impact of food aid on food variety and dietary diversity of an elderly community in Sharpeville, South Africa. J Nutr Health Aging. 2009;13(4):300-308.

67. Steyn NP, Bradshaw D, Norman R, et al. Dietary changes and the health transition in South Africa: implications for health policy. Cape Town: South African Medical Research Council. 2006 [homepage on the Internet]. c2010. Available from: http://www.sahealthinfo.org/lifestyle/dietaccess.htm

68. Dannhauser A, Bester CJ, Joubert G, et al. Nutritional status of preschool children in informal settlement areas near Bloemfontein. Pub Health Nutr. 2000;3(3):303-312.

69. Dannhauser A, Walsh C, Nel M. Nutritional status of disabled schoolchildren in Bloemfontein (20022003). S Afr J Clin Nutr. 2007;20(1):6-14

70. Pedro TM, Mackeowen JM, Norris SA. Variety and total number of food items recorded by a true longitudinal group of urban black South African children at five interceptions between 1995 and 2003 the Birth-to-Twenty (Bt20) Study. Pub Health Nutr. 2008;11(6):626-633.

71. Feeley A, Pettifor JM, Norris SA. Fast-food consumption among 17-year-olds in the Birth-to-Twenty cohort. S Afr J Clin Nutr. 2009;22(3):118-123.

72. Hattingh Z. The relationship between anthropometry, dietary intake and risk for type 2 diabetes mellitus in women (25-44 years) in Mangaung. MTech Food and Nutrition thesis, Technikon Free State; 2002.

73. World Health Organisation (WHO). 2010. Global health observatory [homepage on the Internet]. c2011. Available from http://www.who.int/gho/en/ 